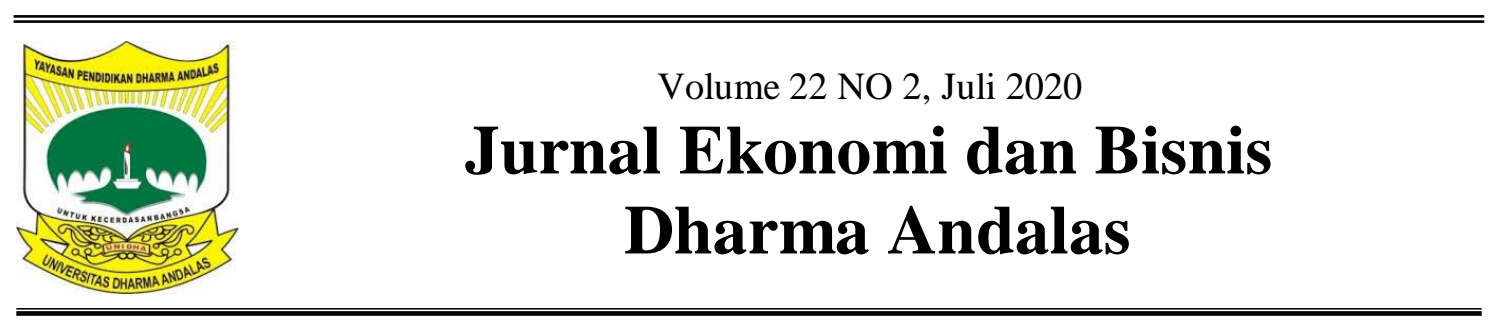

\title{
Analisis Efektifitas dan Efisiensi Pajak Daerah, Retribusi Daerah dan Kontribusinya Terhadap Pendapatan Asli Daerah Kota Bukittinggi
}

\author{
Yenni Del Rosa ${ }^{1}$, Ingra Sovita ${ }^{2}$, Mohammad Abdilla ${ }^{3}$ \\ Fakultas Ekonomi dan Bisnis Universitas Dharma Andalas ${ }^{1,2,3}$ \\ email: rosa.yennidel@yahoo.com ${ }^{1 *}$ \\ ingra75@yahoo.com ${ }^{2}$ \\ m.abdilla@yahoo.co.id ${ }^{3}$
}

\begin{abstract}
The purpose of this study was to determine the effectiveness and efficiency ratios of local taxation, local user fees and the ratio of their contribution to the PAD of Bukittinggi in 2014 2018. The research data were time series data (secondary data) collected through library research and analyzed using quantitative descriptive analysis. The results showed the ratio of the effectiveness of the average local tax and the ratio of the average efficiency of the local tax of Bukittinggi $98.86 \%$ (classified as effective and efficient). The ratio of the effectiveness of the average regional retribution and the ratio of the average efficiency of the regional levy of the city of Bukittinggi $108.91 \%$ (classified as very effective and very efficient). The ratio of the average contribution of local taxes to the Bukittinggi municipal PAD 42.58\% (quite good) and the ratio of the average contribution of the regional levies to the Bukittinggi city PAD $28.10 \%$ (classified as moderate).
\end{abstract}

Keywords: local tax, efficiency and contribution.

\begin{abstract}
ABSTRAK
Tujuan penelitian untuk mengetahui rasio efektifitas dan rasio efisiensi pajak daerah, retribusi daerah dan rasio kontribusinya terhadap PAD kota Bukittinggi tahun 2014 - 2018. Data penelitian berupa data time series (data sekunder) dikumpulkan melalui library research dan dianalisis menggunakan analisis deskriptif kuantitatif. Hasil penelitian menunjukkan rasio efektifitas rata-rata pajak daerah dan rasio efisiensi rata-rata pajak daerah kota Bukittinggi 98.86\% (kategori efektif dan efisien). Rasio efektifitas rata-rata retribusi daerah dan rasio efisiensi rata-rata retribusi daerah kota Bukittinggi $108.91 \%$ (tergolong sangat efektif dan sangat efisien). Rasio kontribusi rata-rata pajak daerah terhadap PAD kota Bukittinggi 42.58\% (cukup baik) dan rasio kontribusi rata-rata retribusi daerah terhadap PAD kota Bukittinggi $28.10 \%$ (sedang).
\end{abstract}

Kata kunci : pajak lokal, efisiensi dan kontribusi

\section{PENDAHULUAN}

Setiap daerah diberi kewenangan

oleh pemerintah pusat untuk mengembangkan semua potensi yang ada didaerahnya guna membiayai pembangunan, mengatur dan mengurus kepentingan masyarakat setempat sesuai pelaksanaan otonomi daerah yang diatur dalam UU No.32/2004. Untuk melaksanakan otonomi daerah yang nyata, dinamis dan bertanggung jawab perlu dana yang besar dan harus 
didukung oleh sumber-sumber penerimaan daerah itu sendiri. Perimbangan keuangan pusat dan daerah merupakan sistem pembiayaan pemerintah dalm kesatuan mencakup pembagian keuangan secara proporsional, demokrasi, adil dan transparan dengan memperhatikan potensi, kondisi dan kebutuhan daerah sesuai UU No.33/2004. Sumber-sumber pendapatan daerah dalam UU No.25/1999 antara lain berasal dari Pendapatan Asli Daerah (PAD) terdiri dari pajak daerah, retribusi daerah, perusahaan milik daerah dan pengelolaan kekayaan daerah yang dipisahkan serta lain-lain PAD yang syah. Dari penerimaan daerah diatas hanya pajak daerah dan retribusi daerah yang menjadi salah satu sumber pembiayaan penyelenggaraan pemerintah dan pembangunan daerah (Deddy, 2001). Retribusi daerah adalah pembayaran dari rakyat kepada pemerintah karena adanya balas jasa yang diterima dari pembayaran tersebut (Suparmoko, 2001). Sesuai UU No.18/1997 retribusi terdiri atas retribusi jasa umum, retribusi jasa usaha dan retribusi perizinan tertentu. Bagi Pemerintah Daerah (Pemda) retribusi daerah lebih berarti karena menjadi sumber utama pendapatan daerah menurut (Devay dkk, 2001). Dengan dilakukannya otonomi daerah pada setiap daerah dibangun pusat kompleks pertokoan yang nantinya setiap bulan membayar retribusi daerah kepada Pemda.

Untuk memaksimalkan otonomi daerah, meningkatkan pembangunan dan mengurangi sumbangan dari Pemerintah Pusat maka Pemda harus lebih meningkatkan PAD dengan menggali semaksimal mungkin sumber-sumber PAD karena PAD salah satu indikator pengukur keberhasilan penyelenggaraan otonomi daerah. Kota Bukittinggi salah satu kota di provinsi Sumatera Barat diberi kewenangan untuk mengatur dan mengelola sumber pendapatan daerahnya sendiri dengan menggali, mengelola dan memaksimalkan potensi sumberdaya yang ada di kota Bukittinggi sebagai sumber PAD. Kota Bukittinggi terkenal dengan berbagai macam objek wisata yang banyak dikunjungi oleh wisatawan domestik dan manca negara sehingga PAD kota Bukittinggi terbesar berasal dari industri pariwisata dengan pajak daerah berasal dari pajak hotel, pajak restoran, pajak hiburan, pajak reklame, pajak penerangan jalan dan pajak Bea Perolehan Hak atas Tanah dan Bangunan (BPTHB) diatur dalam Peraturan Daerah No. 5 / 2012 tentang Pajak Daerah dan Retribusi Daerah sehingga pariwisata dipandang sebagai sumber daya potensial (Wardiyanto, 2011) yang mampu menghasilkan multiplier effect tinggi.

\begin{tabular}{lcr}
\multicolumn{2}{c}{ Efektifitas pajak daerah dan } \\
retribusi daerah & menunjukkan \\
kemempuan & Pemda & dalam
\end{tabular}
mengumpulkan pajak daerah dan retribusi daerah sesuai dengan jumlah penerimaan pajak dan retribusi yang ditargetkan sedangkan efisiensi merupakan pengukur besarnya biaya pemungutan yang digunakan terhadap realisasi penerimaan pajak daerah dan retribusi daerah itu sendiri (Halim, 2004).

Pengukuran efektifitas dan efisiensi pajak daerah serta retribusi daerah sangat penting diketahui guna melihat apakah adanya peningkatan pengelolaan pajak daerah dan retribusi daerah karena pajak daerah dan retribusi daerah merupakan sumber pendapatan daerah untuk membiayai penyelenggaraan pembangunan daerah sesuai dengan UU No. 32 / 2004.

Berdasarkan uraian di atas ternyata jumlah target pajak daerah dan realisasinya, target retribusi daerah dan realisasinya serta target PAD dan realisasinya serta kontribusi pajak 
daerah dan retribusi daerah terhadap PAD kota Bukittinggi tahun 2014 2018 relatif mengalami fluktuasi. Rumusan masalah penelitian untuk mengetahui berapakah besar rasio efektifitas dan rasio efisiensi penerimaan pajak daerah dan retribusi daerah serta rasio kontribusinya terhadap PAD kota Bukittinggi tahun 2014 - 2018. Tujuan penelitian untuk mengetahui rasio efektifitas dan rasio efisiensi pajak daerah, retribusi daerah dan rasio kontribusinya terhadap PAD kota Bukittinggi tahun 2014 - 2018.

\section{Otonomi Daerah}

Otonomi daerah adalah hak, wewenang dan kewajiban daerah otonom untuk mengatut dan mengurus sendiri urusan pemerintahan dan kepentingan masyarakat setempat sesuai peraturan perundang-undangan. Untuk memaksimalkan otonomi daerah dan meningkatkan pembangunan serta mengurangi sumbangan dari Pemerintah Pusat maka Pemda harus lebih meningkatkan PAD. Keuangan daerah suatu bidang di Pemda menentukan besarnya pengeluaran dan penerimaan daerah untuk pembiayaan pembangunan, pelayanan kepada masyarakat dan keperluan daerah lainnya.

$$
\text { Menurut Siahaan (2005) }
$$

keuangan daerah menyangkut PAD, pemberian pemerintah pusat dan sumber lainnya sebagai penerimaan daerah sedangkan pengeluaran berupa biaya rutin dan biaya pembangunan daerah. Masalah biaya pembangunan pemerintah daerah tidak dapat dilaksanakan fungsinya dengan efektif dan efisien tanpa biaya yang cukup untuk memberikan pelayanan dan pembangunan. Keuangan daerah salah satu kriteria untuk mengetahui secara nyata kemampuan daerah dalam mengurus rumah tangganya sendiri (Woyang, 1988). Masalah penting untuk menilai suatu daerah dapat melakukan otonomi sbb; 1) Adanya urusan yang diserahkan oleh perintah atasannya, 2) Pengaturan dan pengurusan yang dilakukan atas inisiatif dan kebijaksanaan sendiri, 3) Mengatur urusan perlengkapan dan aparatur sendiri, 4) Membiayai urusan yang diserahkan sumber keuangan sendiri menurut (Miftah,1985). Keuangan sendiri berupa keuangan daerah adalah semua hak dan kewajiban daerah yang dinilai dengan uang termasuk di dalamnya segala bentuk kekayaan yang berhubungan dengan PP No. 58/ 2005 pasal 1 butir 5 meliputi : 1) Hak daerah untuk melakukan pemungutan pajak daerah dan retribusi daerah serta melakukan pinjaman, 2) Kewajiban daerah menyelenggarakan urusan pemerintahan dan mengelola sumbersumber keuangan daerah, 3) Penerimaan daerah dan pengeluaran daerah, 4) Kekayaan daerah yang dikelola sendiri atau oleh pihak lain berupa uang, surat berharga, piutang, barang serta hal-hal lain yang dapat dinilai dengan uang termasuk kekayaan yang dipisahkan pada perusahaan daerah, 5) Kekayaan pihak lain yang dikuasai oleh pemerintah daerah dan atau kepentingan umum.

\section{Efektifitas Pajak Daerah}

Pajak daerah adalah pajak yang dipungut oleh daerah (provinsi, kabupaten / kota) berdasarkan Perda masing-masing dan hasilnya digunakan untuk pembiayaan rumah tangga daerah masing-masing. Menurut (Mardiasmo, 2011) pajak daerah adalah pajak yang dipungut daerah berdasarkan peraturan yang ditetapkan oleh daerah untuk kepentingan pembiayaan rumah tangga daerah tersebut. Dasar hukum pajak daerah UU No. 28 / 2009 mengatur jenis pajak dan retribusi daerah yang dapat dipungut dan besaran tarif maksimal yang dapat dibebabkan dimana regulasi pemungutan diatur dalam Perda yang diterbitkan oleh Pemda. Jenis pajak daerah yang dimaksud terdiri atas pajak provinsi dan pajak kabupaten/kota. Pajak 
daerah berbentuk keuangan daerah berhubungan dengan otonomi daerah dimana keuangan daerah Menurut (Yani, 2002) adalah semua hak dan kewajiban daerah dalam rangka penyelenggaraan pemerintah daerah yang dinilai dengan uang termasuk segala bentuk kekayaan lain yang berhubungan dengan hak dan kewajiban daerah dalam kerangka Anggaran Pendapatan Belanja Daerah (APBD). Pajak daerah diklasifikan atas pajak pajak hotel dan restoran, pajak hiburan, pajak reklame, pajak penerangan jalanpajak parkir dan pajak air bawah tanah.

Efektifitas pajak daerah adalah kemampuan pemerintah daerah dalam merealisasikan PAD yang direncanakan dibandingkan dengan target yang ditetapkan berdasarkan potensi riil daerah dan efektifitas terkait dengan hasil yang diharapkan dengan hasil yang sesungguhnya dicapai (Mahmudi, 2015). Efektifitas pajak daerah menunjukkan kemampuan Pemda dalam mengumpulkan pajak daerah sesuai dengan jumlah penerimaan pajak daerah yang ditargetkan. Efisiensi pajak daerah berhubungan dengan besarnya biaya pemungutan dengan realisasi penerimaan pajak daerah (Halim, 2004)

\section{Retribusi Daerah}

Retribusi daerah adalah pemungutan daerah sebagai pembayaran atas jasa atau pemberian izin tertentu yang khusus disediakan dan atau diberikan oleh Pemda untuk kepentingan orang pribadi atau badan. Retribusi merupakan iuran pembayaran rakyat kepada pemerintah dimana kita dapat melihat adanya hubungan balas jasa yang langsung diterima dengan adanya pembayaran retribusi (Suparmoko, 2001). Menurut UU No.18/1997 retribusi daerah adalah pungutan daerah sebagai pembayaran atas jasa atau pemberian izin tertentu yang khusus disediakan dan atau diberikan oleh Pemda untuk kepentingan pribadi / badan. Berdasarkan definisi diatas retribusi daerah terdiri atas unsur sbb; 1) Iyuran masyarakat kepada negara berarti retribusi hanya dipungut oleh negara atau pemerintah, 2) Pemungut harus didasarkan pada undang-undang, 3) Hasil pemungutan dapat digunakan untuk membiayai pengeluaran pemerintah.

Sesuai Perda No.8/2002 retribusi toko atau parkir di tepi jalan umum merupakan salah satu bagian dari retribusi daerah yang harus dibayarkan setiap bulannya kepada Dinas Pengelolaan Keuangan dan Aset Daerah (DPKAD). Retribusi toko, parkir di tepi jalan umum merupakan pembayaran yang dilakukan oleh pemilik toko kepada pemerintah dengan biaya retribusi yang berbeda-beda tergantung pada luas toko, lokasi dan waktu pembayaran retribusi (bulanan / harian) khusus untuk pemilik toko dikenakan tarif bulanan. Berdasarkan ketentuan yang ada penetapan tarif pajak dan retribusi daerah harus diusulkan dan ditetapkan melalui Perda yang disetujui oleh pemerintah pusat dan gubernur. Dasar penetapan tarif pajak sebagian kecil telah diatur secara nasional seperti pajak pembangunan terdiri dari pajak makanan dan minuman, pajak hotel. Jenis pajak lain lebih banyak memperhatikan aspek daerah seperti kemampuan rakyat, perkembangan ekonomi daerah dan arus barang / jasa serta tarif pajak di sekitarnya untuk menghindari pelarian wajib pajak dan retribusi.

Efektifitas retribusi daerah merupakan perbandingan antara realisasi dan target penerimaan retribusi daerah sehingga dapat digunakan sebagai ukuran keberhasilan dalam melakukan pemungutan (Halim, 2004 ). Efisiensi retribusi daerah mengukur besarnya biaya pemungutan yang digunakan terhadap realisasi penerimaan retribusi itu sendiri (Halim, 2004 ) 


\section{Pendapatan Asli Daerah}

Pendapatan Asli Daerah (PAD) salah satu sumber penerimaan daerah yang bertujuan memberikan kewenangan kepada Pemda untuk mendanai pelaksanaan pembangunan dan otonomi daerah sesuai dengan potensi daerah sebagai wujud desentralisasi. Menurut (Halim, 2004) PAD adalah semua penerimaan daerah berasal dari sumber ekonomi asli daerah berupa pajak daerah, retribusi daerah, hasil pengelolaan kekayaan milik daerah yang dipisahkan dan lain-lain PAD yang syah. Pendapatan Asli Daerah adalah pendapatan yang diperoleh daerah dipungut berdasarkan Perda sesuai dengan peraturan perundang-undangan. Menurut (UU No. 33 / 2004) pasal 6 sumber PAD dapat dipisahkan menjadi 4 jenis pendapatan yakni sebagai berikut : 1) Pajak daerah, 2) Retribusi daerah, 3) Hasil perusahaan milik daerah dan hasil pengelolaan kekayaan daerah yang dipisahkan, 4) Lain-lain pendapatan PAD yang syah berupa hasil penjualan kekayaan daerah yang dipisahkan, jasa giro, pendapatan bunga, keuntungan selisih tukar nilai rupiah terhadap mata uang asing dan komisi, potongan atau bentuk lain sebagai akibat dari penjualan dan atau pengadaan barang dan atau jasa oleh daerah. Masing-masing pajak daerah akan memberikan kontribusi terhadap PAD dimana (Halim, 2004) menyatakan bahwa kontribusi adalah seberapa besar pengaruh atau peran serta penerimaan pajak daerah terhadap Pendapatan Asli Daerah (PAD).

\section{METODE PENELITIAN}

Data penelitian berupa data sekunder berupa data time series yang diperoleh dari Dinas Pengelolaan Keuangan dan Aset Daerah (DPKAD), Badan Pusat Statistik dan instansi terkait lainnya tentang data berikut :

1. Data target dan realisasi penerimaan pajak daerah kota Bukittinggi tahun
2014 - 2019 dinyatakan dalam milyar rupiah.

2. Data target dan realisasi penerimaan retribusi daerah kota Bukittinggi tahun 2014 - 2018 dinyatakan dalam milyar rupiah.

3. Data target dan realisasi penerimaan PAD kota Bukittinggi tahun 2014 2019 dinyatakan dalam milyar rupiah.

Data penelitian dikumpulkan melalui library research dengan teknik dokumentasi tentang pajak daerah, retribusi daerah dan Pendapatan Asli Daerah (PAD) kota Bukittinggi tahun 2014 - 2018.

\section{Teknik Analisis Data}

1. Analisis Deskriptif Kuantitatif Analisis data penelitian bersifat deskriptif kuantitatif (Sugiyono, 2007). Realisasi penerimaan pajak daerah dan retribusi daerah dihitung dengan cara menjumlahkan penerimaan pajak daerah dan retribusi daerah sesuai klasifikasinya setiap tahun. Potensi pajak daerah dan retribusi retribusi daerah dihitung dengan cara sebagai berikut :

a. Efektifitas potensi pajak hotel = realisasi pajak hotel / 12 bulan $\mathrm{x}$ (pajak rumah kos + pajak hotel + pajak kampung singgahan + pajak home stay) x $100 \%$.

b. Efektifitas potensi pajak hiburan = realisasi pajak hiburan / 12 bulan $\mathrm{x}$ (rata-rata pajak hiburan yang dibayar) x $100 \%$.

c. Efektifitas potensi retribusi pelayanan kesehatan $=$ (realisasi retribusi pelayanan kesehatan) / (pelayanan kesehatan + penjualan obat-obatan hasil farmasi) x $100 \%$.

d. Efektifitas potensi retribusi terminal $=$ (realisasi retribusi terminal $/ 12 \mathrm{x}$ (angkutan pedesaan + AKDP + AKAP) x $100 \%$.

2. Analisis Efektifitas Pajak Daerah Efektifitas pajak daerah adalah nilai yang dihitung berdasarkan persentase perbandingan realisasi penerimaan 
pajak dengan target penerimaan pajak dengan rumus (Hakim, 2013) sbb:

$$
\begin{aligned}
& \text { Efektifitas pajak daerah } \\
& =\frac{\text { realisasi penerimaan pajak daerah }}{\text { target penerimaan pajak daerah }} \times 100 \%
\end{aligned}
$$

dengan kriteria sebagai berikut : diatas $100 \%$ sangat efektif, di atas $90 \%$ $100 \%$ efektif, di atas $80 \%-90 \%$ cukup efektif, di atas 60\% - 80\% kurang efektif dan kurang dari $60 \%$ tidak efektif (Kepmendagri No. 690.900.327 tahun 2006).

\section{Analisis Efektifitas Retribusi Daerah} Efektifitas retribusi daerah adalah nilai yang dihitung berdasarkan persentase perbandingan realisasi penerimaan retribusi daerah dengan target penerimaan retribusi daerah dengan rumus (Hakim, 2013) sebagai berikut :

$$
\begin{aligned}
& \text { Efektifitas retribusi daerah } \\
& =\frac{\text { realisasi penerimaan retribusi daerah }}{\text { target penerimaan retribusi daerah }} \times 100 \% \\
& \text { dihitung sesuai kriteria menurut } \\
& \text { (Kepmendagri No. 690.900.327 } \\
& \text { tahun 2006). }
\end{aligned}
$$

4. Analisis Efisiensi Pajak Daerah Efisiensi pajak daerah adalah nilai yang dihitung berdasarkan persentase biaya pemungutan pajak dibagi realisasi penerimaan pajak daerah dengan rumus (Hakim, 2013) sebagai berikut :

$$
\begin{aligned}
& \text { Efisiensi pajak daerah } \\
& =\frac{\text { biaya pemungutan pajak daerah }}{\text { realisasi penerimaan pajak daerah }} \times 100 \%
\end{aligned}
$$

dengan kriteria efisien bila rasio efisiensi atau rasio biaya pungut tidak melebihi 5\% (Kepmendagri No. 35 tahun 2002).

5. Analisis Efisiensi Retribusi Daerah Efisiensi retribusi daerah adalah nilai yang dihitung berdasarkan persentase perbandingan biaya pemungutan retribusi dengan realisasi penerimaan retribusi dengan rumus (Hakim, 2013) Efisiensi retribusi daerah

$=\frac{\text { biaya pemungutan retribusi daerah }}{\text { realisasi penerimaan retribusi daerah }} \times 100 \%$ dihitung sesuai kriteria (Kepmendagri No. 35 tahun 2002).

6. Analisis Kontribusi Pajak Daerah Terhadap PAD

Kriteria yang digunakan untuk mengetahui besar kontribusi pajak daerah terhadap PAD dengan rumus (Hakim, 2013) sebagai berikut :

$$
\begin{aligned}
& \text { Kontribusi pajak daerah terhadap PAD } \\
& =\frac{\sum \text { realisasi penerimaan pajak daerah }}{\sum \text { realisasi penerimaan PAD }} \times 100 \%
\end{aligned}
$$

Dengan kriteria kontribusinya terhadap PAD sbb : kurang dari 10\% sangat kurang, di atas $10 \%-20 \%$ kurang, di atas 20\% - 30\% sedang, di atas $30 \%$ - 40\% cukup, di atas $40 \%$ $50 \%$ baik dan di atas $50 \%$ sangat baik (Kepmendagri No. 690.900.326 tahun 2006).

7. Analisis Konstribusi Retribusi Daerah Terhadap PAD

Perhitungan ini digunakan untuk mengetahui besar kontribusi retribusi daerah terhadap PAD dengan rumus (Hakim, 2013) sebagai berikut :

Kontribusi retribusi daerah terhadap PAD

$=\frac{\sum \text { realisasi penerimaan retribusi daerah }}{\sum \text { realisasi penerimaan PAD }} \times 100 \%$

dihitung sesuai kriteria (Kepmendagri No. 690.900.327 tahun 2006).

Kerangka berpikir merupakan model konseptual agar teori berhubungan dengan berbagai faktor yang diidentifikasi sebagai masalah penting dalam penelitian seperti gambar 1 berikut :

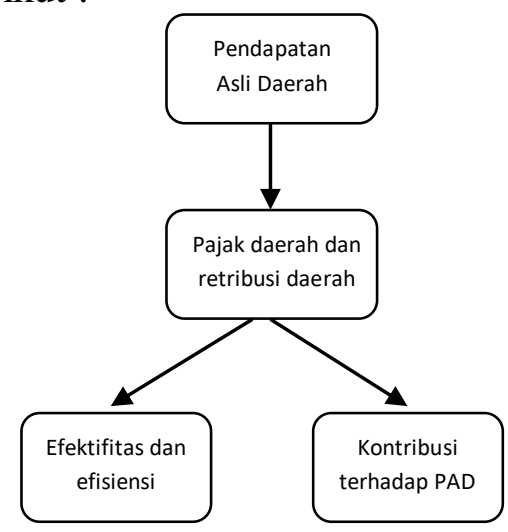

Gambar 1 Model Konseptual 
HASIL DAN PEMBAHASAN

Sebelum dilakukan analisis data terlebih dahulu perlu diperhatikan potensi penerimaan pajak daerah karena nantinya akan berkaitan dalam menentukan rasio efektifitas, rasio efisiensi dan rasio kontribusi seperti tabel 1 berikut

\section{Tabel 1}

Proyeksi Realisasi Penerimaan Pajak Daerah Kota Bukittinggi

\begin{tabular}{|c|c|c|c|c|c|c|c|c|}
\hline \multirow[t]{2}{*}{ No } & \multirow{2}{*}{$\begin{array}{l}\text { Pajak } \\
\text { Daerah }\end{array}$} & \multirow{2}{*}{$\begin{array}{c}\text { Potensi } \\
\text { Penerimaan } \\
2015\end{array}$} & \multirow{2}{*}{$\begin{array}{l}\text { Rata-Rata } \\
\text { Pertumbuhan }\end{array}$} & \multicolumn{5}{|c|}{ Tahun } \\
\hline & & & & 2016 & 2017 & 2018 & 2019 & 2020 \\
\hline 1. & $\begin{array}{l}\text { Pajak } \\
\text { hotel }\end{array}$ & 9.838 .138 .484 & $8 \%$ & 10.625 .189 .563 & 11.475 .204 .728 & 12.393 .221 .106 & 13.384 .678 .795 & 14.455 .453 .099 \\
\hline 2. & $\begin{array}{l}\text { Pajak } \\
\text { restoran }\end{array}$ & 4.957.914.002 & $13 \%$ & 5.602 .442 .822 & 6.330 .760 .389 & 7.153 .759 .240 & 8.083.747.941 & 9.134 .635 .173 \\
\hline 3. & $\begin{array}{l}\text { Pajak } \\
\text { hiburan }\end{array}$ & 955.177 .822 & $2 \%$ & 974.281 .378 & 993.767 .006 & 1.013 .642 .346 & 1.033.915.193 & 1.054.593.497 \\
\hline 4. & $\begin{array}{l}\text { Pajak } \\
\text { reklame }\end{array}$ & 182.614 .115 & $18 \%$ & 215.483 .829 & 254.269 .943 & 300.037 .382 & 354.042 .752 & 417.768 .845 \\
\hline 5. & $\begin{array}{l}\text { Pajak } \\
\text { peneranga } \\
\mathrm{n} \text { jalan }\end{array}$ & 5.776899 .139 & $12 \%$ & 6.470 .127 .036 & 7.246 .542 .280 & 8.116 .127 .354 & 9.090 .062 .636 & 10.180 .870 .153 \\
\hline 6. & $\begin{array}{l}\text { Pajak } \\
\text { parkir }\end{array}$ & 106.388 .505 & $10 \%$ & 117.027 .356 & 128.730 .091 & 141.603 .100 & 155.763 .410 & 171.339 .751 \\
\hline 7. & $\begin{array}{l}\text { Pajak air } \\
\text { tanah }\end{array}$ & 48.487 .075 & $8.04 \%$ & 52.386 .043 & 56.598 .537 & 61.149 .768 & 66.066 .975 & 71.379 .588 \\
\hline 8. & $\begin{array}{l}\text { Pajak } \\
\text { BPHTB }\end{array}$ & 6.608 .174 .805 & $9.38 \%$ & 7.228.263.078 & 7.906.538.290 & 8.648 .460 .503 & 9.460 .002 .130 & 10.347 .696 .018 \\
\hline & Total & 28.473.793.948 & & 31.285.201.105 & 34.392 .411 .264 & 37.828 .000 .799 & 41.628 .279 .833 & 45.833 .736 .122 \\
\hline
\end{tabular}

Sumber : Data Diolah, 2020

Berdasarkan tabel 1 di atas sumber Pendapatan Asli Daerah (PAD) kota Bukittinggi berasal dari pajak daerah seperti pajak hotel, pajak restoran, pajak hiburan, pajak reklame, pajak penerangan jalan, pajak parkir, pajak air tanah dan pajak Bea Perolehan Hak atas Tanah dan Bangunan (BPHTB) dengan total proyeksi realisasi penerimaan tahun 2020 berdasarkan tahun dasar tahun 2015 sebanyak Rp 45.833.756.122,-. Penerimaan pajak daerah kota Bukittinggi paling tinggi berasal dari pajak hotel kemudian diikuti oleh pajak penerangan jalan dan pajak BPHTB berarti ketiga jenis pajak ini akan memberikan kontribusi terbanyak terhadap PAD. Sementara potensi penerimaan pajak daerah kurang $\mathrm{Rp}$ 1.000.000.000,- seperti pajak reklame, pajak parkir, pajak air tanah masih belum bisa memberikan kontribusi terhadap PAD kota Bukittinggi.

\section{Perhitungan Rasio Efektifitas Pajak Daerah}

Bentuk pajak daerah yang dipungut oleh pemerintah kota Bukittinggi sesuai UU No. 28 / 2009 berupa pajak hotel, pajak restoran, pajak hiburan, pajak reklame, pajak penerangan jalan, pajak parkir, pajak air tanah dan pajak Bea Perolehan Hak atas Tanah dan Bangunan (BPHTB). Pajak daerah yang belum / tidak dipungut oleh pemerintah kota Bukittinggi berupa pajak mineral bukan logam dan batuan, serta pajak sarang burung walet. Perhitungan rasio efektifitas pajak daerah kota Bukittinggi seperti pada tabel 2 berikut :

Tabel 2

\section{Rasio Efektifitas Pajak Daerah Kota} Bukittinggi

\begin{tabular}{ccccc}
\hline \multirow{2}{*}{ Tahun } & \multicolumn{2}{c}{ Pajak Daerah (Rp) } & $\begin{array}{c}\text { Rasio } \\
\text { Efektifitas }\end{array}$ & Kriteria \\
\cline { 2 - 3 } & \multicolumn{2}{c}{ Target } & Realisasi & \\
\hline 2014 & 26.982 .218 .901 & 27.314 .752 .524 & 101.23 & $\begin{array}{r}\text { Sangat } \\
\text { efektif }\end{array}$
\end{tabular}




\begin{tabular}{ccccc}
\hline \multirow{2}{*}{ Tahun } & \multicolumn{2}{c}{ Pajak Daerah (Rp) } & $\begin{array}{c}\text { Rasio } \\
\text { Efektifitas }\end{array}$ & Kriteria \\
\cline { 2 - 4 } 2015 & 27.855 .512 .078 & 29.002 .326 .911 & 104.12 & $\begin{array}{l}\text { Sangat } \\
\text { efektif }\end{array}$ \\
\cline { 3 - 4 } 2016 & 34.758 .804 .463 & 30.709 .233 .356 & 88.35 & $\begin{array}{l}\text { Cukup } \\
\text { efektif }\end{array}$ \\
2017 & 37.927 .583 .059 & 38.282 .322 .400 & 100.94 & $\begin{array}{l}\text { Sangat } \\
\text { efektif }\end{array}$ \\
2018 & 45.293 .035 .421 & 45.131 .000 .000 & 99.64 & Efektif \\
\hline
\end{tabular}

Sumber : Data Diolah, 2020.

Berdasarkan tabel 2 di atas rasio efektifitas pajak daerah kota Bukittinggi tahun 2014 - 2018 ternyata sangat efektif tahun 2014, 2015 dan 2017, cukup efektif tahun 2016 dan efektif 2018 dengan rasio efektifitas rata-ratanya sebesar $98.86 \%$ (kriteria efektif). Hal ini menunjukkan bahwa pajak daerah kota Bukittinggi selama 5 tahun relatif belum efektif dimanfaatkan secara optimal untuk meningkatkan pendapatan daerah terlihat dari angka rasio efektifitas rataratanya sebesar $98.86 \%$. Dalam hal ini pajak daerah tahun 2020 paling efektif (lebih dari $\mathrm{Rp} 1.000 .000 .000$ ) berasal dari penerimaan sebagai berikut : Pertama, pajak hotel (hotel bintang1, bintang2, bintang 3, bintang 4, holtel melati dan lainnya) dengan estimasi realisasi potensi penerimaan $\mathrm{Rp}$ 14.455.453.099,- Kedua, pajak restoran (rumah makan pakai bill dan rumah makan pakai ketetapan) dengan estimasi realisasi potensi penerimaan $\mathrm{Rp}$ 9.134.635.173,-. Ketiga, pajak hiburan (pajak tontonan, pajak hiburan lainnya) dengan estimasi realisasi potensi penerimaan $\mathrm{Rp}$ 1.054.593.497,- diatur sesuai Perda kota Bukittinggi No. 9 / 2012 dengan subjek pajak hiburan orang pribadi atau badan yang menikmati hiburan dan wajib pajak hiburan adalah orang pribadi atau badan yang menyelenggarakan hiburan. Keempat, pajak penerangan jalan estimasi realisasi potensi penerimaan $\mathrm{Rp} 10.180 .870 .153$ pemungutannya diatur dalam Perda kota Bukittinggi No. 1 / 2004 dimana objek pajak penerangan adalah penggunaan tenaga listrik yang dihasilkan sendiri maupun yang diperoleh dari sumber lain. Wajib pajak penerangan adalah orang pribadi atau badan yang menggunakan tenaga listrik serta dasar pengenaan pajak penerangan jalan adalh nilai jual tenaga listrik. Kelima, pajak BPHTB pemungutannya diatur dalam Perda kota Bukittinggi No. 3 / 2011 dimana objek pajak BPHTB adalah perolehan hak atas tanah dan atau bangunan. Dasar pengenaaan BPHTB adalah nilai perolehan objek pajak dan tarif BPHTB ditetapkan paling tinggi sebesar 5\% dengan estimasi realisasi potensi penerimaan sebesar Rp 10.347.696.018,- Kelima jenis pajak ini mampu melampaui target peneriman pajak daerah yang telah ditetapkan. Beberapa jenis pajak daerah yang kurang efektif penerimaannya karena potensi penerimaan pajaknya di bawah $\mathrm{Rp}$ 1.000.000.000,- berasal dari pajak reklame estimasi realisasi potensi penerimaan Rp 417.768.845,- pajak parkir estimasi realisasi potensi penerimaan Rp 191.339.751,- karena jumlah lokasi parkir di kota Bukittinggi tidak banyak dan pajak air bawah tanah estimasi realisasi potensi penerimaan $\mathrm{Rp}$ 71.379.588,- dimana pemungutan pajak ini mempunyai kendala karena hanya menggunakan self assessment system sehingga sulit untuk memantau jumlah pemakaian air tanah dari masing-masing wajib pajak.

\section{Perhitungan Rasio Efektifitas Retribusi Daerah}

Perhitungan rasio efektifitas retribusi daerah kota Bukittinggi seperti pada tabel 3 berikut :

Tabel 3

Rasio Efektifitas Retribusi Daerah Kota Bukittinggi

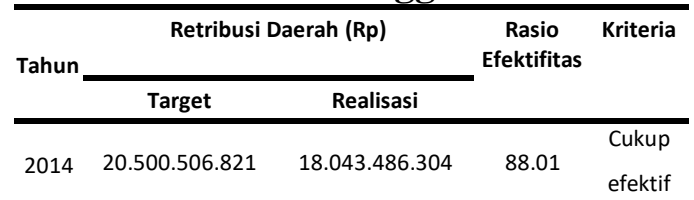




\begin{tabular}{|c|c|c|c|c|}
\hline \multirow{2}{*}{ Tahun } & \multicolumn{2}{|c|}{ Retribusi Daerah (Rp) } & \multirow{2}{*}{$\begin{array}{c}\text { Rasio } \\
\text { Efektifitas }\end{array}$} & \multirow[t]{2}{*}{ Kriteria } \\
\hline & Target & Realisasi & & \\
\hline 2015 & 20.372 .528 .431 & 17.032 .759 .085 & 83.61 & $\begin{array}{l}\text { Cukup } \\
\text { efektif }\end{array}$ \\
\hline 2016 & 17.991 .825 .075 & 21.070 .000 .000 & 117.11 & $\begin{array}{l}\text { Sangat } \\
\text { efektif }\end{array}$ \\
\hline 2017 & 19.006.564.009 & 27.329 .000 .000 & 143.79 & $\begin{array}{l}\text { Sangat } \\
\text { efektif }\end{array}$ \\
\hline 2018 & 26.723.908.061 & 29.943 .000 .000 & 112.05 & $\begin{array}{l}\text { Sangat } \\
\text { efektif }\end{array}$ \\
\hline
\end{tabular}

Sumber : Data Diolah, 2020.

Berdasarkan tabel 3 di atas rasio efektifitas retribusi daerah kota Bukittinggi tahun 2014 - 2018 ternyata sangat efektif tahun 2016, 2017 dan 2018 dan hanya cukup efektif tahun 2014, 2015 dengan rasio efektifitas rataratanya sebesar $108.91 \%$ (kriteria sangat efektif). Hal ini menunjukkan bahwa retribusi daerah kota Bukittinggi selama 5 tahun relatif sangat efektif dimanfaatkan secara optimal untuk meningkatkan PAD terlihat dari angka rasio efektifitas rata-ratanya sebesar $108.91 \%$. Penerimaan retribusi daerah kota Bukittinggi sangat efektif berasal dari retribusi jasa usaha dan retribusi jasa umum serta yang tidak efektif penerimaannya berasal dari retribusi perizinan tertentu sehingga menyebabkan belum tercapainya target retribusi daerah karena masih adanya permasalahan seperti kurangnya jumlah personil pemungut retribusi dan masih kurangnya kepatuhan masyarakat dalam membayar uang retribusi. Pemerintah kota Bukittinggi untuk mengoptimalkan retribusi daerah berupaya meningkatkan kegiatan penyuluhan kepada masyarakat guna menumbuhkan kesadaran membayar retribusi daerah.

\section{Perhitungan Rasio Efisiensi Pajak Daerah}

Perhitungan Rasio Efisiensi Pajak Daerah Bukittinggi. Perhitungan ini berguna untuk melihat apakah pajak yang dipungut oleh pemerintah Kota Bukit Tinggi sudah secara efisiensi digunakan untuk meningkatkan PAD. Perhitungannya dapat dilihat pada tabel 4 berikut :

\section{Tabel 4}

\begin{tabular}{|c|c|c|c|c|}
\hline Tahun & Target & Realisasi & $\begin{array}{l}\text { Rasio } \\
\text { Efisiensi }\end{array}$ & Kriteria \\
\hline 2014 & 26.982.218.901 & 27.314.752.524 & 101.23 & Sangat \\
\hline 2015 & 27.855 .512 .078 & 29.002.326.911 & 104.12 & Sangat \\
\hline 2016 & 34.758 .804 .463 & 30.709 .233 .356 & 88.35 & Efisiensi \\
\hline 2017 & 37.927.583.059 & 38.282 .322 .400 & 100.94 & $\begin{array}{l}\text { Sangat } \\
\text { efisiensi }\end{array}$ \\
\hline 2018 & 45.293 .035 .421 & 45.131 .000 .000 & 99.64 & Efisiensi \\
\hline
\end{tabular}

Sumber : Data Diolah, 2020.

Berdasarkan tabel 4 di atas rasio efisiensi pajak daerah kota Bukittinggi tahun 2014 - 2018 ternyata sangat efisien tahun 2014, 2015 dan 2017, efisiensi tahun 2016, 2018 dengan rasio efisiensi rata-ratanya sebesar $98.86 \%$ (kriteria efisiensi). Hal ini menunjukkan bahwa pajak daerah kota Bukittinggi selama 5 tahun relatif belum dimanfaatkan secara efisiensi untuk meningkatkan PAD kota Bukittinggi.

\section{Perhitungan Rasio Efisiensi Retribusi Daerah}

Perhitungan rasio efisiensi retribusi daerah kota Bukittinggi seperti pada tabel 5 berikut :

\section{Tabel 5}

Rasio Efisiensi Retribusi Daerah Kota Bukittinggi

\begin{tabular}{ccccc}
\hline \multirow{2}{*}{ Tahun } & \multicolumn{2}{c}{ Retribusi Daerah (Rp)) } & $\begin{array}{c}\text { Rasio } \\
\text { Efisiensi }\end{array}$ & Kriteria \\
\cline { 2 - 3 } & Target & Realisasi & & \\
\hline 2014 & 20.500 .506 .821 & 18.043 .486 .304 & 88.01 & $\begin{array}{c}\text { Cukup } \\
\text { efisiensi }\end{array}$ \\
2015 & 20.372 .528 .431 & 17.032 .759 .085 & 83.61 & $\begin{array}{c}\text { Cukup } \\
\text { efisiensi }\end{array}$ \\
2016 & 17.991 .825 .075 & 21.070 .000 .000 & 117.11 & $\begin{array}{c}\text { Sangat } \\
\text { efisiensi }\end{array}$ \\
2017 & 19.006 .564 .009 & 27.329 .000 .000 & 143.79 & $\begin{array}{c}\text { Sangat } \\
\text { efisiensi } \\
\text { Sangat } \\
\text { efisiensi }\end{array}$ \\
\hline
\end{tabular}

Sumber : Data Diolah, 2020. 
Berdasarkan tabel 5 di atas efisisiensi retribusi daerah kota Bukittinggi tahun 2014 - 2018 ternyata sangat efisien tahun 2016, 2017 dan 2018 hanya cukup efisiensi tahun 2014, 2015 dengan rasio efisiensi rata-ratanya sebesar $108.91 \%$ (kriteria sangat efisiensi). Hal ini menunjukkan bahwa retribusi daerah kota Bukitinggi selama 5 tahun relatif sangat efisiensi dimanfaatkan secara optimal untuk meningkatkan PAD kota Bukittinggi.

Kontribusi Pajak Daerah Terhadap Pendapatan Asli Daerah

Perhitungan kontribusi pajak daerah terhadap PAD kota Bukittinggi seperti tabel 6. berikut :

\section{Tabel 6}

Kontribusi Pajak Daerah Terhadap PAD Kota Bukittinggi

\begin{tabular}{ccccc}
\hline Tahun & $\begin{array}{c}\text { Realisasi Pajak } \\
\text { Daerah (Rp) }\end{array}$ & $\begin{array}{c}\text { Realisasi PAD } \\
\text { (Rp) }\end{array}$ & $\begin{array}{c}\text { Rasio } \\
\text { Kontribusi }\end{array}$ & Kriteria \\
\hline 2014 & 27.314 .752 .524 & 61.615 .347 .589 & 44.33 & Baik \\
2015 & 29.002 .326 .911 & 66.029 .044 .130 & 43.92 & Baik \\
2016 & 30.709 .233 .356 & 71.302 .466 .356 & 43.07 & Baik \\
2017 & 38.282 .322 .400 & 102.374 .322 .400 & 37.39 & $\begin{array}{c}\text { Cukup } \\
\text { Baik }\end{array}$ \\
2018 & 45.131 .000 .000 & 101.937 .840 .823 & 44.27 & Baik \\
\hline Sumber: Data Diolah, 2020.
\end{tabular}

Sumber : Data Diolah, 2020.

Berdasarkan tabel 6 di atas kontribusi pajak daerah terhadap PAD kota Bukittinggi tahun 2014 - 2018 ternyata baik tahun 2014, 2015, 2016 dan 2018 hanya cukup baik tahun 2017 dengan rasio kontribusi rata-ratanya sebesar $42.58 \%$ (kriteria cukup baik). Hal ini menunjukkan bahwa kontribusi pajak daerah kota Bukitinggi selama 5 tahun relatif cukup baik dimanfaatkan secara optimal untuk meningkatkan PAD terlihat dari angka rasio kontribusi rataratanya sebesar $42.58 \%$. Kontribusi pajak daerah terhadap PAD kota Bukittinggi secara umum kontribusinya masih kurang dimana jenis pajak daerah yang paling banyak memberikan kontribusi terhadap PAD kota Bukittinggi berasal dari penerimaan pajak hotel dan yang terkecil berasal dari penerimaan pajak air bawah tanah. Agar kontribusi pajak daerah terhadap PAD kota Bukittinggi sangat baik maka pemerintah kota Bukittinggi perlu menerapkan pembayaran pajak daerah secara on line, meningkatkan pelayanan dan perlindungan kepada masyarakat dengan memberikan kesadaran dalam membayar pajak daerah.

Kontribusi Retribusi Daerah Terhadap Pendapatan Asli Daerah

Perhitungan kontribusi retribusi daerah terhadap PAD kota Bukittinggi seperti tabel 7 berikut

\section{Tabel 7}

Kontribusi Retribusi Daerah Terhadap PAD Kota Bukittinggi

\begin{tabular}{ccccc}
\hline Tahun & $\begin{array}{c}\text { Realisasi } \\
\text { Retribusi } \\
\text { Daerah }\end{array}$ & Realisasi PAD & $\begin{array}{c}\text { Rasio } \\
\text { Kontribusi }\end{array}$ & Kriteria \\
\hline 2014 & 18.043 .486 .304 & 61.615 .347 .589 & 29.28 & Sedang \\
2015 & 17.032 .759 .085 & 66.029 .044 .131 & 25.80 & Sedang \\
2016 & 21.070 .000 .000 & 71.302 .466 .356 & 29.55 & Sedang \\
2017 & 27.329 .000 .000 & 102.374 .322 .400 & 26.70 & Sedang \\
2018 & 29.723 .908 .061 & 101.937 .840 .823 & 29.16 & Sedang \\
\hline
\end{tabular}

Sumber : Data Diolah, 2020.

Berdasarkan tabel 7 di atas kontribusi retribusi daerah terhadap PAD kota Bukittinggi tahun 2014 2018 sedang dengan rasio kontribusi rata-ratanya sebesar $28.10 \%$ (kriteria sedang). Hal ini menunjukkan bahwa kontribusi retribusi daerah kota Bukitinggi selama 5 tahun relatif sedang dimanfaatkan secara optimal untuk meningkatkan PAD terlihat dari angka rasio kontribusi rata-ratanya sebesar 28.10\%. Kontribusi retribusi daerah paling besar terhadap PAD kota Bukittinggi diberikan oleh jasa usaha dan retribusi jasa umum serta kontribusi retribusi daerah paling kecil terhadap PAD kota Bukittinggi diberikan oleh retribusi perizinan tertentu sehingga target retribusi daerah kota Bukittinggi belum tercapai secara optimal.

Implikasi Tingkat Efektifitas dan Efisiensi Pajak Daerah, Retribusi Daerah dan PAD 
Dengan memperhatikan angkaangka efektifitas dan efisiensi sesuai tabel di atas selanjutnya diperoleh implikasi dalam upaya meningkatkan penerimaan pajak daerah dan retribusi daerah sebagai salah satu sumber PAD kota Bukittinggi diantaranya sebagai berikut :

\section{Intensifikasi}

Merupakan usaha untuk meningkatkan jumlah penerimaan retribusi daerah dengan tidak merubah sumber penerimaan baru atau dengan kata lain bagaimana cara mengelola yang telah ada menjadi sumber penerimaan daerah yang baik dengan mengidentifikasi pemungutan retribusi daerah dan mengefisiensikan cara pemungutannya pada subjek dan objek yang sudah dikenakan pajak sebelumnya. Upaya yang dapat dilakukan untuk mengidentifikasi pemungutan retribusi daerah sebagai berikut :

- Meningkatkan pengetahuan tentang retribusi daerah, dengan memberikan kesadaran kepada masyarakat dalam membayar retribusi daerah.Tujuan ini dapat dicapai melalui kerjasama dengan berbagai organisasi kemasyarakatan,pemuka agama dan pemuka masyarakat dalam bentuk penyuluhan.Salah satu indikator keberhasilannya yakni menurunnya jumlah tunggakan retribusi daerah.

- Meningkatkan manajemen dalam bentuk pembenahan administrasi dengan cara mempermudah urusan dalam organisasi dan mekanisme kontrol yang lebih baik. Sehingga tercapainya sistem administrasi yang efektif dan efisien dalam meningkatkan pelayanan kepada pemakai jasa.

- Meningkatkan mutu pelayanan, dengan menyederhanakan prosedur pembayaran retribusi daerah,tempat pembayaran yang lebih mudah untuk dicapai, melengkapi prasarana yang cukup baik dengan berbagai kenyamanan pada lokasi pembayaran retribusi daerah.

- Penyesuaian terhadap tarif dengan tujuan agar tidak terlalu sering melakukan perubahan sesuai Perda yang berlaku agar tidak menimbulkan gejolak dalam masyarakat.

2. Ekstensitas

Merupakan penerimaan retribusi daerah yaitu usaha untuk meningkatkan penerimaan retribusi daerah dengan cara memperluas dan menambah sumber-sumber penerimaan baru serta meng aktifkan,mengembangkan,menggali sumber-sumber penerimaan yang ada. Mobilitas dan faktor sosial ekonomi masyarakat juga dapat mempengaruhi penerimaan retribusi daerah sehingga perlu menjalin kerjasama dengan berbagai pihak untuk mengantisipasi semua kemungkinan yang terjadi yang dapat mengurangi penerimaan retribusi daerah .Implikasi kebijakan penerimaan retribusi daerah yakni mencari terobosan baru sesuai ketentuan berlaku dan melakukan pendataan ulang terhadap wajib pajak retribusi daerah.

\section{SIMPULAN}

Etimasi realisasi potensi penerimaan pajak daerah tahun 2020 berasal dari pajak hotel, pajak restoran, pajak hiburan, pajak penerangan jalan dan pajak BPHTB dimana yang paling tinggi estimasi realisasi potensi penerimaannya berasal dari pajak hotel, BPHTB dan pajak penerangan jalan. Rata-rata rasio efektifitas pajak daerah 98.86\% berarti pajak daerah belum efektif dimanfaatkan secara optimal oleh Pemko Bukittinggi. Rata-rata rasio retribusi daerah $108,91 \%$ berarti retribusi daerah telah sangat efektif dimanfaaatkan secara optimal oleh 
Pemko Bukittinggi. Rata-rata rasio efisiensi pajak daerah $98.86 \%$ berarti pajak daerah telah efisiensi dimanfaatkan secara optimal oleh Pemko Bukittinggi. Rata-rata efisiensi retribusi daerah $108.91 \%$ berarti retribusi daerah telah sangat efisien dimanfaatkan oleh Pemko Bukittinggi. Rata-rata kontribusi pajak daerah terhadap PAD $42.58 \%$ berarti pajak daerah cukup baik dimanfatkan oleh Pemko Bukittinggi untuk meningkatkan PAD dengan adanya sistem mekanisme kontrol Kontribusi retribusi daerah terhadap PAD $28.10 \%$ berarti retribusi daerah belum cukup baik dimanfaatkan oleh Pemko Bukittinggi untuk meningkatkan PAD, hal ini dapat ditingkatkan dengan memperhatikan berbagai implikasi kebijakan dari pemerintah.

Penerimaan pajak daerah dan retribusi daerah kota Bukittinggi tergolong baik hendaknya dapat dipertahankan di samping itu hendaknya juga harus ditingkatkan. Dalam upaya meningkatkan penerimaan pajak daerah dan retribusi daerah perlu dilakukan disiplin waktu bagi wajib pajak dalam pembayarannya agar tidak menunggak sehingga tidak memberatkan bagi wajib pajak...

\section{DAFTAR PUSTAKA}

Badan Pusat Statistik. Bukittinggi Dalam Angka 2019. Bukittinggi : Badan Pusat Statistik.

Brata Kusumah, Deddy.1996. Otonomi Penyelenggaraan Pemerintah Daerah. Jurnal Ekonomi dan Manajemen. 34(1).

Devay,K.J. 2001. Pembiayaan Pemerintah Daerah. Jakarta : Universitas Indonesia Presss.

Hakim, Vita Amaliah. 2013. Analisis Efektifitas Pajak Daerah dan Retribusi Daerah Terhadap Pendapatan Asli Daerah Kota Tasikmalaya (Studi Kasus Pada Dinas Pendapatan Kota
Tasikmalayaa.

Skripsi

Universitas Siliwangi .

Halim, Abdul. 2004. Akuntansi Keuangan Daerah. Jakarta : Salemba Empat.

Keputusan Menteri Dalam Negeri No. 35 tahun 2002 tentang Nilai Efisiensi Retribusi Daerah.

Keputusan Menteri Dalam Negeri No. 35 tahun 690.900.327 tahun 2006 tentang Nilai Efektifitas

Pajak Daerah.

Mahmudi.2015. Analisis Laporan Pemerintah Keuangan Daerah Edisi Ketiga. Yogyakarta : STIM YKPN.

Mardiasmo. 2011. Perpajakan. Yogyakarta : Andi.

Miftah,Toha. 2001. Manajemen Pembangunan Daerah Tingkat II. Jurnal Prisma No.12.

Siahaan, Marihot P. 2005. Pajak Daerah dan Retribusi Daerah. Jakarta : PT Raja Grafindo Persada.

Sugiyono. 2007. Metode Penelitian Kualitatif dan Kuantitatif $R \& D$. Jakarta : Alfabeta.

Undang-Undang No. 32 tahun 2004 Tentang Pemerintah Daerah

Undang-Undang No. 33 tahun 2004 Tentang Perimbangan Keuangan Pemerintah Pusat dan

Pemerintah Daerah.

Undang-Undang No. 28 tahun 2009 Tentang Pajak Daerah dan Retribusi Daerah.

Wardiyanto. 2011. Perencanaan Pengembangan Pariwisata. Bandung : Lubuk Agung.

Yani, Ahmad. 2002. Hubungan Keuangan Pemerintah Pusat dan Daerah di Indonesia. Jakarta : PT Raja Grafindo Persada.

Woyang,J.2001. Administrasi Keuangan Daerah Cetakan Ke 4. Jakarta : Penerbit Ikhtiar 